\title{
Financial Statement and Competitiveness Analysis: A Study on Tourism $\&$ Hospitality Industry in Bangladesh
}

\author{
Tanvir Mohammad Hayder Arif ${ }^{1}$, Kazi Noor-E- Jannat ${ }^{2} \&$ S.M. Rakibul Anwar ${ }^{2}$ \\ ${ }^{1}$ Associate Professor, Department of Finance, University of Chittagong, Chittagong, Bangladesh \\ ${ }^{2}$ Lecturer, Department of Finance, Cox's Bazar International University, Cox's Bazar, Bangladesh \\ Correspondence: Tanvir Mohammad Hayder Arif, MSc. International Business Management (UK), Associate \\ Professor, Department of Finance, University of Chittagong, Chittagong, Bangladesh. E-mail: tanvir.arif@cu.ac.bd
}

Received: June 4, 2016

Accepted: July 13, 2016

Online Published: July 18, 2016

doi:10.5430/ijfr.v7n4p180

URL: http://dx.doi.org/10.5430/ijfr.v7n4p180

\begin{abstract}
The core objective of this paper is to uplift the feasibility of hotel industry of Cox's Bazar of Bangladesh. Here the analysis of the financial statement of the most standard hotel has been made. Standard methods are used to collect information. Both primary and secondary sources are used. For research purpose financial information of five popular local hotel of Cox's Bazar, Hotel the Seagull, The Cox Today, The Ocean Paradise, The Sayman and The long Beach hotel has been collected. Firstly, in the literature review, the importance of financial performance analysis using different financial statement and uses of ratio analysis has been shown. Financial statements of hotels of Cox's Bazar are mainly used to orchestrate this research. The findings show the performance of the hotel industry over the last five years. Here gradually hotel industry performing well compared to the previous years. Ratio analysis and trend analysis conducted to analyze the financial position and feasibility of hotel industry. This research has shown the enlightening and profitable future of hotel industry in Cox's Bazar. Because some popular capital budgeting techniques like Payback period, Accounting Rate of Return and Net present value are used and these techniques give a positive result in all case.
\end{abstract}

Keywords: feasibility, financial statement, hotel, Cox’s Bazar, Bangladesh

\section{Introduction}

The hospitality industry is one of the world's fast-moving industries. The role of this industry in worldwide economic growth is indisputable. According to the Tourist Research and Forecasts tourism and hospitality industry add values to country GDP about $20 \%$ and fosters employment by about 7, 00,000 jobs (Papaikos, 1999). According to ICAP annuals survey report tourism will surpass 60 billion and investments in this industry will touch 12 billion, constituting $13 \%$ of total investments and employment will appear around 800000 jobs, granting $17 \%$ in the total investment. (ICAP cited in Chouliaras, 2006)

Cox's Bazar allures many tourists because of its natural beauty and longest sea beach and based on this, there comprise many hotel businesses to serve them. This tourism and hospitality industry plays a vital role in the economy. The hospitality industry is a large field within the service industry that includes smaller fields such as hotels and lodging, event planning, theme parks, transportation, cruise lines and other fields within the tourism industry. Financial statement analysis helps to get a clear picture of a business enterprise. This paper analyzes the growth of tourism and hospitality industry through different ratios. These ratios computed from different financial statements like income statement and balance sheet. With the hospitality industry being a general one, it is extremely important to define a set of financial ratios that can be used to analyze companies across the entire industry, regardless of operations. The hospitality industry is heavy in fixed and tangible assets and therefore requires a very specific set of financial ratios to accurately analyze the industry and come to conclusions based on the performance of individual companies.

The main objective of the study is to ascertain plausibility of the tourism and hospitality sector of Bangladesh.

The specific objectives are:

- To evaluate and analyze the current financial position of tourism and hospitality industry.

- To compare its performances of the last five years from 2011 to 2015.

- To predict the growth of this sector. 


\subsection{Implications of Financial Statement Analysis}

A financial statement is the mirror image of company's true financial position. Shareholders' and as well as stakeholders' get a clear idea regarding the company by properly analyzing its financial statement. Through a financial statement analysis investors determine financial feasibility, profitability, and growth. It ensures stakeholders' and company management to take a rational and relevant decision and to evaluate production trend, pricing strategy, and operational efficiency (Singh et al., 2015).

\subsection{Financial Statement Analysis}

In this study, this paper focuses on ratio analysis of the tourism and hospitality industry of Cox's Bazar, Bangladesh over the last five years. The ratio is the numerical expression of data. Through ratio analysis, investors get proper information about the working efficiency, profitability and the solvency capacity of the organization. Ratio analysis is a tool arrogated to find out the quantitative relationship between two or more financial data obtained from financial statements. As some ratio possess a well-defined feature, so one can easily get a constructive idea from it (Bhattacharya, 2011).

Ratios are classified based on four category-liquidity ratios, solvency capacity ratio, activity ratio and profitability ratio. Liquidity ratio indicates firm's short-term solvency capacity; through solvency capacity ratio investor ascertain firm's ability to meet long-term obligations. Activity ratio measures firm's efficiency to use it assets, leverage and other and profitability ratio highlights current efficiency and working efficiency of the organizations. (Sing et al., 2015)

\section{Literature Review}

Hales (2005) stated that financial statement analysis is necessary to forecast future based on past analysis. Financial statement analysis can be made on daily, weekly, monthly and quarterly report basis. Manager determines overall performance and productivity of each segment of their core business. Employees' productivity can be judged by measuring productivity in the past and gauging the same in the future. (Bell et al., 1986)

Company uses four basic types of following financial statement:

- Balance sheet

- Income Statement

- Cash flow Statement

- Statements of shareholders equity.

These statements represent the company to many stakeholders. The proper understanding of these statements is very important for the managers to collect financial information and make the right decision (Hales, 2011). This information helps manager greatly in hotel valuation and evaluating hotels sales, cost, and profitability levels (Angelo \& Vladimir, 2011). Since $18^{\text {th }}$-century ratio analysis is widely used for the study of the financial data. Financial ratios assist the analyst to observe the financial condition of a company (Lawder cited in Asadullah \& Rehman, 2015). Although there are various techniques used for financial ratio analysis, but hotel industry uses very few techniques (Kim \&Ayoun, 2005). Balance sheet and income statement are the major sources of financial information that are used in calculating financial ratios (Dong Jin Kim, 2006). Mericet and his colleagues made a comparison of financial ratios of different organization of many countries (Meric et al, 1997; 2002; 2004). Many scholars and researchers have drawn same conclusions regarding such comparisons as the firms of these segments are radically homogeneous (Smith, 1997; Zaman \& Unsal, 2000; Locke \&Scrimgeoun, 2003).

Ratio analysis is a major tool used by management to observe current performance and compare it with the predetermined standards. As a result, steps can be taken based on the deviation between actual and standard performances. There are three types of abroad group of the user who are interested in the evaluation of ratios: operating management, creditors and company shareholders (Jagles \& Ralston).

Management and operational strategies and a number of efficient employees strongly affect the success of a hotel. Managers are responsible for productive use of the asset by minimizing cost and maximizing profit.

Ratio analysis is a major technique used to monitor the overall performance of organizations and compares it with the predetermined standard. The Sectoral study of ICAP (2006) found some important points, which are given below:

1. Category B hotel generally has the highest profit. (Approximately $32 \%$ ).

2. Operating profit margin and return on equity are negative in case of luxury hotels.

3. The $\mathrm{B}$ category hotel has the highest return on equity ratio.

4. The liquidity ratio of $\mathrm{B}$ class hotel is also good enough. 
John Myer (1983) stated that in the initial years of the $20^{\text {th }}$ century the bank and securities exchange authorities were substantially reckoned on the financial statements of the companies for measuring the performance of business.

\section{Research Methodology}

Quantitative and qualitative data both have a major influence on a research. Quantitative data gives information in the numeric form as a result statistical test can be applied and as all the information is from financial statements, it is helpful in making investment decisions. Qualitative studies describe the qualities or feature of something. As some information cannot be structured in a numeric form that's why this paper gathers more information regarding behavior, opinions, patterns, needs and other types of information. Actually, qualitative data is useful to identify the factors that affect the areas under investigation, and then use that information to assist quantitative research that determines how these factors would user preferences. According to Bless (200:103), non-participants observations, participants observations, interview \& questionnaire are the key types of qualitative data collection method. In this research paper, the methods used for the analysis have following three steps:

\subsection{Sample Identification and Selection}

Here the top class hotels have been identified for the analysis. For research purpose, financial information of five popular local hotel of Cox's Bazar such as The Seagull, The Cox Today, The Ocean Paradise, The Sayeman and The long Beach hotel has been collected. In terms of the sampling, this paper has used 'randomly' sampling method and selected these five hotels on the basis of their strategic plans, service quality and their positioning in the current market. As these hotels are of same quality their average financial information of last five years have been reported here. Data analysis involves skimming (superficial examination), reading (through examination) and interpretation. The main reason to use these hotels as a sample for this research is that these hotels are well-reputed and best choices of most of the domestic and international tourists (Survey). These hotels have a greater influence on the whole hospitality industry.

\subsection{Data Collection}

Most information is collected from primary sources by using interview method. Both Qualitative and quantitative method has been used. Here financial statement has been used as a secondary source of information and individual hotel performance is critically measured. To have a proper understanding offinancial statement and computing ratio and trend of the hospitality industry average of all financial information of all hotels has been selected.

\subsection{Data Analysis}

To investigate the future performances and profitability of hotel and tourism industry all information is critically analyzed. Ratio analysis and trend analysis used to properly evaluate this industry. As the sample was chosen almost are homogeneous so this analysis provides better understandings to the investor. Capital Budgeting techniques help investor regarding the proper project selection and making an investment decision. This paper shows that the tourism and hospitality industry has thriving future as its trends are upwording.

\section{Findings \& Analysis}

Table 1. Ratio analysis over the last five years

\begin{tabular}{|c|c|c|c|c|c|c|}
\hline Different ratios & 2011 & 2012 & 2013 & 2014 & 2015 & $\begin{array}{c}\text { Average } \\
\text { Ratio }\end{array}$ \\
\hline Return On Capital & 5.714 & 1.333 & 4.917 & 7.061 & 22.355 & 8.276 \\
\hline Return On Equity & 5.714 & 1.333 & 4.917 & 7.061 & 22.355 & 8.276 \\
\hline Gross Profit Ratio & 65.000 & 47.500 & 69.231 & 81.000 & 92.800 & 71.106 \\
\hline Operating Profit Ratio & 40.000 & 12.500 & 45.385 & 60.017 & 83.607 & 48.302 \\
\hline Inventory Turnover & 3.889 & 5.185 & 3.333 & 3.800 & 3.789 & 3.999 \\
\hline Debtors Collection & 18.250 & 29.656 & 15.442 & 18.250 & 11.315 & 18.583 \\
\hline Current Ratio & 3.625 & 2.508 & 2.667 & 5.000 & 8.125 & 4.385 \\
\hline Quick Ratio & 2.500 & 1.885 & 1.667 & 4.000 & 6.938 & 3.398 \\
\hline Capital Gearing Ratio & 3.708 & 2.889 & 19.672 & 16.190 & 98.421 & 28.176 \\
\hline Debt to Equity ratio & 0.270 & 0.346 & 0.051 & 0.062 & 0.010 & 0.148 \\
\hline Interest Coverage Ratio & 0.030 & 0.006 & 0.121 & 0.157 & 2.322 & 0.527 \\
\hline
\end{tabular}

Source: Financial Statements of five selected hotels of Cox's Bazar 


\subsection{Evaluation of Performance on Profitability}

ROE: Here we see ROE increases because of additional investment and for tremendous growth in net income. ROE encircles the three pillars of corporate management profitability, asset management, and financial leverage. Here ROE proves that the hotel management is efficient enough to get the job done. If we see, return on equity at 2015 was so good in comparison to previous year.

Return on Capital employed: It is used to gauge a company's efficiency at allocating the capital under its control to profitable investments. Here return on capital employed increased due to the proper utilization of fund in profitable section.

Gross Profit: Is a profitability ratio that shows the relationship between gross profit and total net sales revenue. Here we see there is a gradual growth in gross profit ratio, which is a good sign. That means hotel management is doing better in their operational performance, which leads increasing stock turnover and increasing sales volume. Here we see average gross profit ratio is 71.01615 .

Operating Profit: Operating profit ratio is also increasing. The hotel is performing well and it is using its working capital more efficiently that in turn has affected operating profit positively.

\subsection{Evaluation of Performance on Liquidity}

Current Ratio: Here the average current ratio is 4.3848 indicates management managing its liquidity ratio perfectly to hold proper liquidity position.

Acid Test Ratio: Management maintains a stable quick ratio that is good enough. It shows firm meets its short-term obligations just in time.

\subsection{Evaluation of Performance on Investment}

Gearing: Here capital gearing ratio is also increasing. That means management is trying to maintain an optimum capital structure.

Debt to equity: Here we see there is a decline in debt to equity ratio in the current year that reveals the less utilization of long-term debt.

Interest coverage ratio: Here we see that interest coverage ratio increased in the current year. That means the company is efficient enough to bear its fixed expenses. It happened due to increasing amount of cash sales and company maintains stable credit sale.

\subsection{Evaluation of Performance of Management Efficiency}

Stock turnover (times): Here we see stock turnover is almost stable over the five years but management is trying to improve more.

Debtor's collection days: We know that the less time is required to collect the debtor's amount is better. Here the industry is doing well because gradually collection period is reducing.

\section{Trend Analysis}

Trend analysis is the systematic and chronological process where information is presented through graph and comparison of business is made over time to show any consistent result or trend. Trend analysis postulates the feature of ratio and represents company's performance over the time. It is a technique to get clear concept regarding financial statements and evaluate the company's performance directions. (Jr., 2014) By properly analyzing the trend manager can critically observe the ratios movement and determine the financial viability whether it is going good, better, best or worst. (Brigham et al, 2015) 


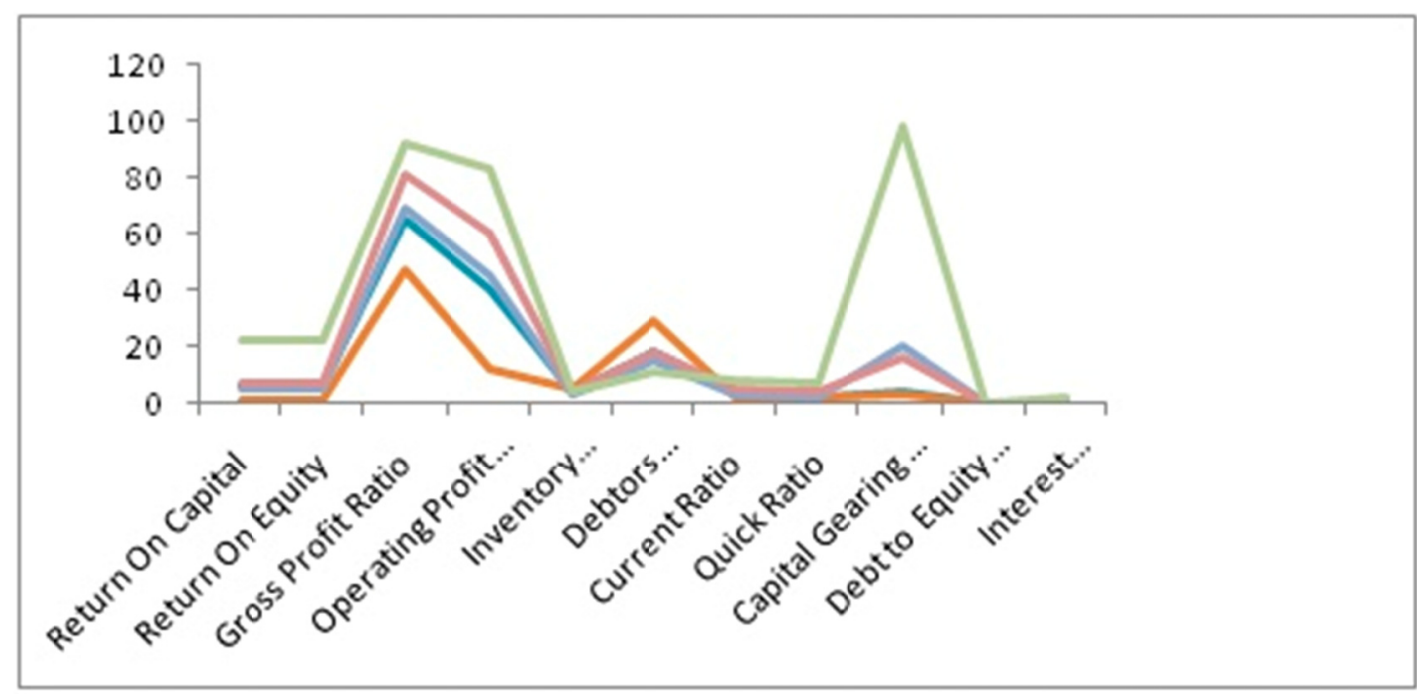

Figure 1. Ratios over the five years

Source: Financial Statements of five selected hotels of Cox’s Bazar

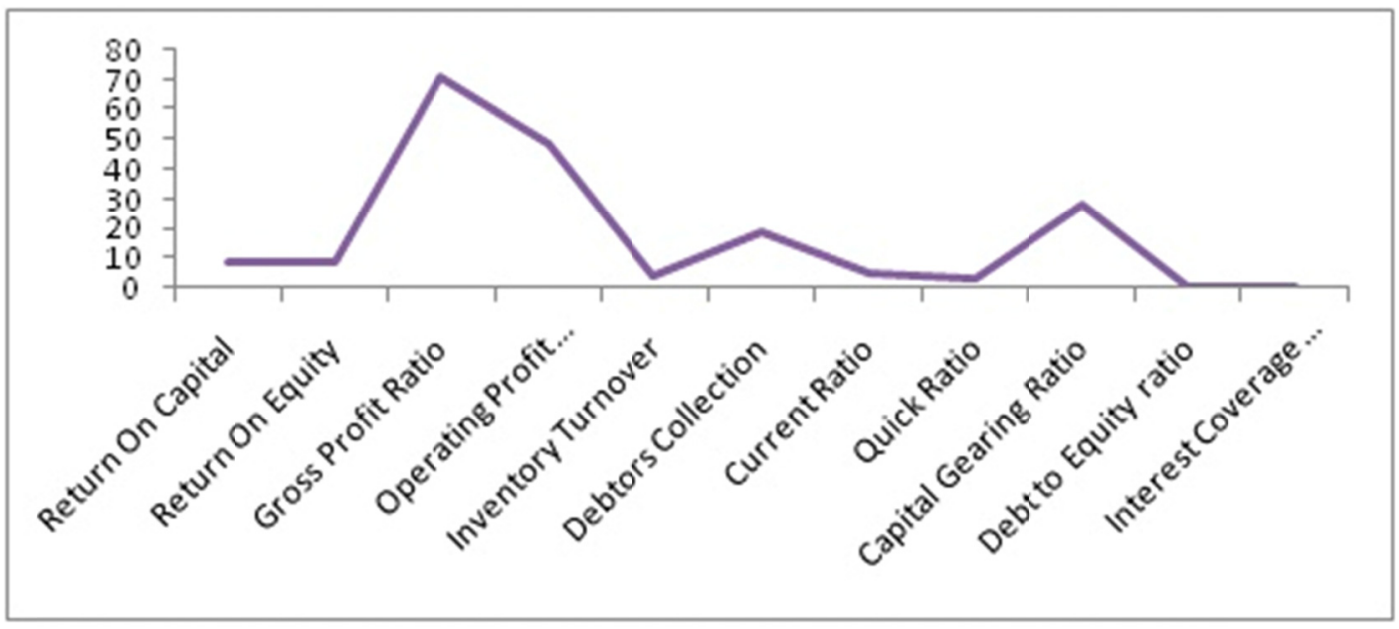

Figure 2. Average ratios over the five years

Source: Financial Statements of five selected hotels of Cox's Bazar

\section{Working Capital Cycle}

The management of working capital entails managing inventories, accounts receivable, payable and cash like any other business hotels to have operating cycle, which begins with the purchase of supplies and ends with the collection of accounts receivable, sufficient working capital is required to sustain sales activity during the operating cycle period.

Working capital management is a fundamental issue to keep business financially competitive in case of restricted access to the short-term fund. Proper analysis of working capital helps manage to applause overall current position of the firm and to take necessary initiatives to handle the fund effectively by more rigorous monitoring and planning of collections, disbursements, and balances. Managers identify problems and the cause of the problem, better cash management and proper coordination between accounts receivable and accounts payable (Signer, 2014). 


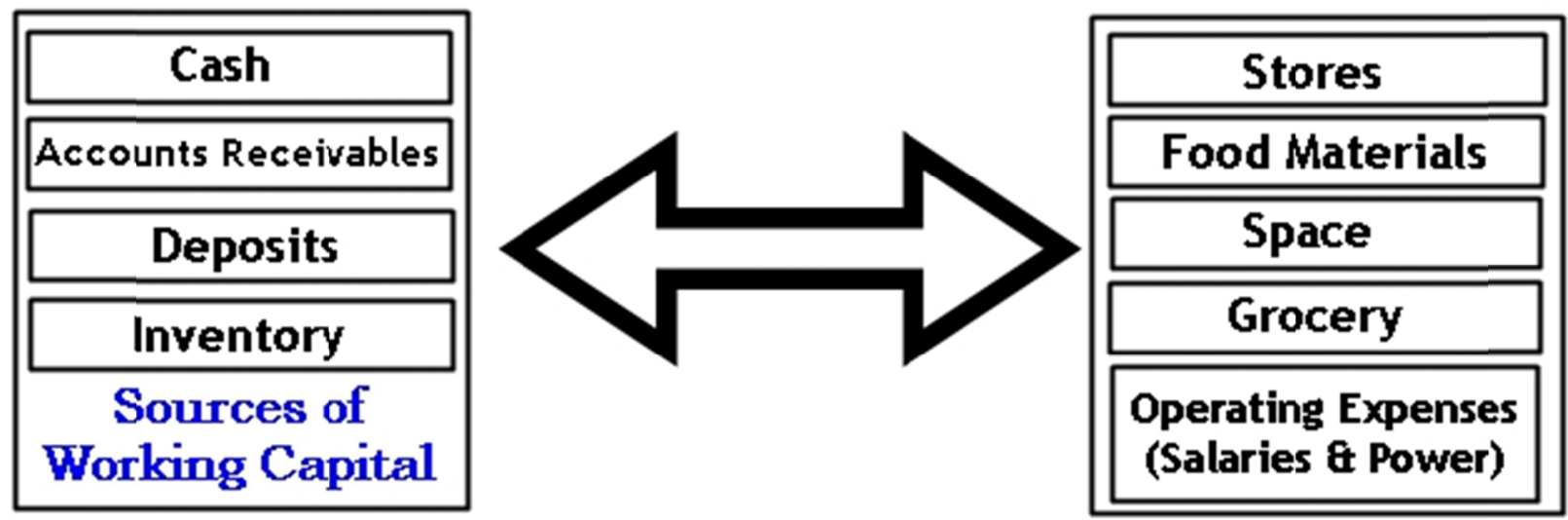

Here hotel management manages its working capital in a well-organized manner. As we see, it does not have any account payable during the current year as well as in previous year, it only holds inventory and accounts receivable. As a result, it ensures proper utilization of funds in managing short-term obligations and requirements easily.

\section{Competitiveness Analysis}

\subsection{Profitability and Optimality Analysis}

Investors need to take long-term decisions on the investments and capital expenditure. They use the fund to invest in those assets that will generate cash for several years in the future. Generally, capital budgeting decisions depend on the company's project selection criteria and investments alternatives like expansion decision, replacement decision etc (Baker, 2011).The manager uses different types of capital budgeting techniques to decide on capital investment and capital spending for the long term. They follow certain steps and analyze several investments alternatives by applying proper techniques (Graham et al, 2012). This part of the study will be helpful for the new investors who are interested to invest in the tourism and hospitality sector of Cox's Bazar in Bangladesh. All the relevant values are forecasted based on the experiences of the Board of Directors of five selected hotels.

\subsubsection{Payback Period (PBP)}

Table 2. Computation table for PBP

\begin{tabular}{lrrrrr}
\hline Year & $\mathbf{2 0 1 1}$ & $\mathbf{2 0 1 2}$ & $\mathbf{2 0 1 3}$ & $\mathbf{2 0 1 4}$ & $\mathbf{2 0 1 5}$ \\
\hline Net Income & 40000000 & 10000000 & 59000000 & 120033000 & 418033000 \\
Cumulative Net Income & 40000000 & 50000000 & 109000000 & 229033000 & 647066000 \\
\hline
\end{tabular}

Source: Calculation based on the figures provided by the managers of the selected hotels.

Payback Period:

$$
\begin{aligned}
\mathrm{PBP} & =\mathrm{A}+(\mathrm{NCO}-\mathrm{C}) / \mathrm{D} \\
& =3+(180000000-109000000) / 120033000 \\
& =3.5915 \text { year }
\end{aligned}
$$

Here $\mathrm{A}=3$

NCO or Net Cash Outflow $=180000000$ and $C=109000000$, Cumulative cash flow at year A.

In addition, $\mathrm{D}=120033000$, Net income following the year $\mathrm{A}$.

7.1.2 Accounting Rate of Return (ARR)

$$
\begin{aligned}
\mathrm{ARR} & =(\text { Average Income/Average Investment }) * 100 \\
& =((647066000 / 5) / 180000000) * 100 \\
& =71.8962222
\end{aligned}
$$




\subsubsection{Net Present Value}

Table 3. Computation table for NPV

\begin{tabular}{lrrrrr}
\hline \multicolumn{1}{c}{ Year } & \multicolumn{1}{c}{$\mathbf{2 0 1 1}$} & \multicolumn{1}{c}{$\mathbf{2 0 1 2}$} & \multicolumn{1}{c}{$\mathbf{2 0 1 3}$} & \multicolumn{1}{c}{$\mathbf{2 0 1 4}$} & \multicolumn{1}{c}{$\mathbf{2 0 1 5}$} \\
\hline Net Income & 40000000 & 10000000 & 59000000 & 120033000 & 418033000 \\
Discounting Factor 15\% & .8696 & .7561 & .6575 & .5718 & .4972 \\
Present value of cash inflow & 34782608.7 & 7561437 & 38793457.7 & 68629257.33 & 207836282.2 \\
\hline
\end{tabular}

Source: Calculation based on the figures provided by the managers of the selected hotels.

$$
\begin{aligned}
\text { Net present value }= & \text { Present value of cash inflow - Initial Investment } \\
= & \mathrm{FV} /(1+\mathrm{r})^{\mathrm{n}-} \text { Investment } \\
= & \quad(34782608.7+7561437+38793457.7+68629257.33 \\
& \quad+207836282.2)-180000000 \\
= & 357603042.6-180000000 \\
= & 177603042.6
\end{aligned}
$$

\subsection{Critical Analysis}

Here Payback period (PBP) is very low, which is 3.5915 year. According to capital budgeting decision rule when PBP is, lower the proposal should be accepted. Again, Accounting Rate of Return (ARR) is also very high. Here banking interest rate is $15 \%$ and ARR is $71.89 \%$, which is higher than the banking interest rate, so can easily, said that this is an acceptable project. On the other hand, NPV gives a positive value at $15 \%$ discounting rate. All findings and analysis has manifested very lucrative future of this industry. Ratio and trend analysis possess rising feature, which is positive sign for the investor. From these calculated values, authors can conclude that tourism and hospitality industry is still a lucrative field of investment for new investors.

\section{Major Sources of Finance Available to Hotel Business}

\subsection{Sources of Finance}

HVS Global Hospitality Services (2015) stated, "The hotel industry has gradually improved over the last 25 years. Although it was difficult to collect any sources of finance in the early 1990 but with the continued success of the hotel industry, lenders are more willing to loan valid hotel projects" According to HVS the following companies provide financing to the hotel business:

- Commercial Banks

- Life Insurance Companies

- Private Credit Companies

- Pension Funds

Investors need to take some crucial decision regarding capital structure of the company. Whether total capital is fully levered by external debt or equity financing? Debt to equity ratio is the indicator of the optimum capital structure. The pattern of the source of financing for listed or established companies is quite different from a new comer (Yartey, 2014).

In the case of hotel business in Cox's Bazar, they use both internal and external sources of finance.

\subsection{Internal Sources of Finance}
* Startup capital
* Retained Profit
- Collection of debt
- Selling of fixed asset 


\subsubsection{Startup Capitals}

In this analysis according to field survey, researchers found that owners at first invest his saving or source as ascertain portion of capital because of starting a business cannot be financed by an external source. Most of the case bank loan used as common external sources of finance. Owners does not want to bear much interest at an initial level that is why they use their own fund as a part of the capital. Most of the time non-native and native investors use their personal or family savings as a major internal source of financing for startup capital. Different categories of a loan from the bank and financial institutions are also used (Constant et al., 2013).

\subsubsection{Retained Profit}

Retained earnings are a major type of internal source of financing. Owners keep a portion of profit and invest back to the business instead of taking a loan from the bank to avoid payment of interest (Stimpson et al., 2015).

Here we have collected data on the hotel that is trading more than five years and we find that most of the time they keep some portion of their profit for future investment. As in Cox's Bazar, these hotels not listed under stock exchange they do not need to follow a dividend policy. However, they retain a portion of profit for further investment and the rest they distribute among the partners.

\subsubsection{Collection of Debt}

We have found that most of the hotels are trading based on a cash sale. They raise fund also from their debtors although they do not maintain a huge amount of credit sale as it is a service oriented business. If they have any credit sale, they collect the fund within their estimated collection period as they have very good receivable collection period.

\subsubsection{Selling of Fixed Asset}

In Cox's Bazar, most of the hotel raise fund by selling fixed assets like a piece of machinery, unused furniture, and unused land. However, these types of sources not used in a routine manner like others.

\subsection{External Sources of Finance}

\section{* Bank Loan \\ * Bank Overdraft}

\subsubsection{Bank Loan}

In our research, we see that hotels in Cox's Bazar use bank loan as main external sources of finance. They use both long-term and short-term loan at the stated interest rate. Most VIP tourists settle their transaction with the hotel via the bank. Hotel management bears their all fixed expenses like electricity bill, salary, and other expenses through the bank transaction. As results, there build a good relationship between bank and hotel business which in turns make it easier to get the loan

\subsubsection{Bank Overdraft}

There is a good relationship between bank and hotel. The company can withdraw a certain amount of fund beyond their deposit according to banks stated rules of the line of credit based on deposit.

\section{Factors Affecting Sources of Finance}

In the case of the external source of financing most of the time, investor prefers borrowing from the bank. Bank verifies the information provided by the loanee before sanctioning the loan. Based on the loan amount, bank collects necessary information without discouraging customer. If bank predicts that, the project perceived risk is higher than they demand more information before sanctioning the loan. (Industrial System Research, 2013)

The source of finance chosen will depend on a number of factors:
$>$ Overall cost
$>$ Financial stability
$>$ Form of business
$>$ Core objective and time
$>$ Risk \& return profile
$>$ Controlling Mechanism
$>$ Reliability 


\section{Conclusions}

This paper investigates the financial viability of tourism and hospitality industry and financial information provided by these five hotels let this paper to gain its core objectives. As Bangladesh achieved international recognition due to its natural beauty and obviously, for the longest sea beach, every year many tourists come to visit this longest sea beach. Therefore, Bangladesh has a very shining future in tourism and hospitality industry. To explore the future profitability of this sector this paper followed a systematic approach of financial statement analysis. Ratio analysis conducted as it allows investor to critically analyze the industry's present and future performance. Trend analysis assists investor to inspect the future growth or project future based on historical performance. This paper also evaluates the working capital management system of these five hotels. Short-term asset and short-term liabilities are effectively propagated so that management can hold the standard and ensure smooth operations. This paper acquired some enthralling and important issues related source of financing and factors affecting the source of finance. As banking, institutions play a vital role to finance this industry they pay great attention during sanctioning any finance. As a result, hotel industry becomes more cautious regarding these factors because it wants to hold good image to its stakeholders and shareholders. Overall this paper successfully prove that the tourism and hospitality sector of Bangladesh specially in Cox's Bazar has very booming future that attracts many investor day by day.

\section{References}

Abbott, F. L. (2013). The Management of Business Lending a Survey. Manchester: Industrial System Research.

Asadullah, M., \& Rehman, Z. (2015). A comparative study on financial performance of hotel industry in Pakistan (serena hotel \& Marriott hotel). Journal of Tourism, Hospitality and Sports, 8, 42-54. http://www.iiste.org/Journals/index.php/JTHS/article/download/22820/22731

Baker, H. K., \& English, P. (2011). Capital Budgeting Valuation, Financial Analysis for Today's Investment Projects. Canada: John Wiley \& Sons Inc. http://dx.doi.org/10.1002/9781118258422

Bhattacharya, D. (2011). Management Accounting. India: Dorling Kindersley.

Bless, C., Smith, H. C., \& Kagee, A. (2007). Fundamentals of Social Research Methods: An African Perspective. South Africa: Juta Legal and Academic Publishers.

Brigham, F. E., \& Ehrhardt, C. M. (2015). Corporate Finance: A Focused Approach. USA: Boston,Cenage Learning.

Chouliaras, V. (2006). Analyzing income statement of 3 star hotels in Thessaloniki. Journal of Tourism and Hospitality Management, 18(1), 83-93. http://hrcak.srce.hr/file/124708

Constant, A. F., \& Zimmermann, K. F. (2013). International Handbook on the Economics of Migration. USA : Edward Elgar Publications. http://dx.doi.org/10.4337/9781782546078

Financial Statement of Hotel Long Beach. (2011-15). Retrieved from www.longbeachhotelbd.com

Financial Statement of Hotel Ocean Paradise. (2011-15). Retrieved from www.oceanparadisehotel.com

Financial Statement of Hotel Sayeman. (2011-15). Retrieved from https://www.tripadvisor.com/Hotel_Review-g667467-d7736740-Reviews-Sayeman_Beach_Resort-Cox_s_Baza r_Chittagong_Division.html

Financial Statement of Hotel Seagull. (2011-15). Retrieved from www.seagullhotelbd.com

Financial Statement of Hotel The Cox Today. (2011-15). Retrieved from www.hotelthecoxtoday.com

Graham, J., \& Smart, S. B. (2012). Introduction to Corporate Finance. USA: Cenage Learning.

Hales, J. (2005). Accounting and financial Analysis in the hospitality industry. USA: Elseveir.

Hales, J. (2011). Accounting \& Financial Analysis in the Hospitality Industry: The use of reason in argument. USA: Elsevier.

Hampton, J. (1983). Financial Decision Making: concepts, problems, and cases. Prentice Hall of India, New Delhi.

HVS Global Hospitality service. (2015). Hotel investment handbook- capital sources and financing. North America: Author.

Jagles, M., \& Ralston, C. (2006). Hospitality Management Accounting. USA :Wiley.

Jr. S. D. (2014). Accountancy. Agra, India: SBPD Publications. 
Kim, J. D. (2006). A comparative study of financial ratios between hotels and restaurants. International Journal of Tourism Science, 6(1), 95-106. http://dx.doi.org/10.1080/15980634.2006.11434589

Kim, W., \&Ayoun, B. (2005). Ratio analysis for the hospitality industry: a cross sector comparison of financial trends in the lodging, restaurants, airline and amusement sectors. Journal of Hospitality Financial Management, 13(1), 1-33. http://dx.doi.org/10.1080/10913211.2005.10653800

Papanikos, G. (2000). Greek small and medium sized hotel companies. Institute of Tourism Research \& Forecasting, Athens.

Sagner, J. (2014). Working Capital Management: Application \& Case studies. New York: Wiley.

Sing, S. K., \& Chauhan, S. (2015). Accountancy. Agra, India: SBPD Publications.

Sing, S. K., \& Gupta, S. (2015). Entrepreneurship with practical. India: SBPD Publications.

Stipson, P., \& Smith, A. (2015). Business Management. UK: Cambrian Printers Ltd.

Yartey, A. C. (2006). The stock market and the financing of corporate growth in Africa: the case of Ghana. (Working Paper No. 06/201). International Monetary fund. http://dx.doi.org/10.5089/9781451864618.001 